\title{
Characteristics and health risk assessment of fine particulate matter and surface ozone: results from Bengaluru, India
}

\author{
Vignesh Prabhu ${ }^{(1)} \cdot$ Pratima Singh • \\ Padmavati Kulkarni $\cdot$ V. Sreekanth $(1)$
}

Received: 2 November 2021 / Accepted: 5 February 2022 / Published online: 23 February 2022

(C) The Author(s), under exclusive licence to Springer Nature Switzerland AG 2022

\begin{abstract}
Urban air pollution is a complex problem, which requires a multi-pronged approach to understand its dynamics. In the current study, various aspects of air pollution over Bengaluru city were studied utilizing simultaneous reference-grade measurements (during the period July 2019 to June 2020) of fine particulate matter mass concentration $\left(\mathrm{PM}_{2.5}\right)$, aerosol black carbon mass concentrations (BC), and surface ozone $\left(\mathrm{O}_{3}\right)$ concentrations. The study period mean $\mathrm{PM}_{2.5}$, $\mathrm{BC}$, and $\mathrm{O}_{3}$ were observed to be $26.8 \pm 11.5 \mu \mathrm{g} \mathrm{m} \mathrm{m}^{-3}$, $5.6 \pm 2.8 \mu \mathrm{g} \mathrm{m}^{-3}$, and $25.5 \pm 12.4 \mathrm{ppb}$, respectively. Statistical methods such as principal component analysis, moving average subtraction method, conditional bivariate probability function, and concentration weighted trajectory analysis were performed to understand the dynamics of air pollution over Bengaluru and its long-range transportation pathways.
\end{abstract}

Supplementary information The online version contains supplementary material available at https://doi. org/10.1007/s10661-022-09852-6.

V. Prabhu $(\bowtie) \cdot$ P. Singh $\cdot$ P. Kulkarni $\cdot$ V. Sreekanth Center for Study of Science, Technology and Policy, Bengaluru 560094, India

e-mail: vp88fri@gmail.com

P. Singh

e-mail: pratima@cstep.in

P. Kulkarni

e-mail: padma.narl@gmail.com

V. Sreekanth

e-mail: sree_hcu@yahoo.co.in
Some of the major findings from the statistical analyses include (i) contrasting association in $\mathrm{BC}$ versus $\mathrm{O}_{3}$ and $\mathrm{PM}_{2.5}$ versus $\mathrm{O}_{3}$; (ii) around one-fourth of the observed receptor site $\mathrm{BC}$ was contributed by local sources/emissions; and (iii) the source locations potentially contributing to $\mathrm{BC}$ and $\mathrm{PM}_{2.5}$ were spatially different. In Bengaluru, long-term exposure to $\mathrm{PM}_{2.5}$ resulted in around 3413, 3393, 1016, and 147 attributable deaths for the health endpoints chronic obstructive pulmonary disorder, ischemic heart disease, stroke, and lung cancer, respectively. Long-term exposure to $\mathrm{O}_{3}$ resulted in around 155 attributable deaths for respiratory diseases, as estimated by the AirQ+model. Finally, the limitations of the study in terms of data availability and analysis have been detailed.

Keywords AirQ $+\cdot$ Black carbon $\cdot \mathrm{CBPF} \cdot \mathrm{PM}_{2.5}$

\section{Introduction}

Worldwide, air pollution was observed to be the fourth highest risk factor associated with deaths (Abbafati et al., 2020). Short- and long-term exposure to air pollution have been linked to various health issues leading to mortality and morbidity (Gurung \& Bell, 2012). Over the last two decades, the South Asian region has been witnessing a 2-6 fold increase in atmospheric aerosol emissions due to the burgeoning rise in population, energy consumption, and industrialization 
(Lawrence \& Lelieveld, 2010). The World Health Organization (WHO) has identified several pollution hotspots over the South Asian region. To combat air pollution in India, the National Clean Air Programme (NCAP) has identified 122 non-attainment cities (characterized by poor air quality) and has set a target of 20-30\% reduction in ambient particulate pollution concentrations by the year 2024 (2017 as the base year; Ganguly et al., 2020).

To combat air pollution, identification of pollution sources and their share quantification plays a vital role. Conventional source apportionment exercise (based on chemical characterization and receptor modeling) helps to identify and quantify the contribution of various sources to the observed ambient pollution concentrations at the receptor sites. In addition, some statistical tools mentioned in the literature are able to identify the source locations by combining the pollutant time series and meteorological data. These tools include conditional bivariate probability function (CBPF) (Carslaw \& Ropkins, 2012), concentration weighted trajectory analysis (CWT) (Seibert, 1994), and principal source contributing function (PSCF) (Ashbaugh et al., 1985). In addition, to decompose the high-resolution time series pollutant data into local and regional shares, techniques such as "successive moving average subtraction method" (Watson \& Chow, 2001) and "under-writing function" were proposed and implemented in some earlier studies (e.g., Kumar et al., 2018).

Bengaluru, a South Indian inland city, was also labeled as one of the non-attainment cities due to its high particulate pollution levels. Emissions from transportation, industries, open waste burning, and domestic cooking are the largest contributors to PM pollution in Bengaluru (Guttikunda et al., 2019). Combustion emissions are generally rich in carbonaceous aerosols, nitrogen oxides, and volatile organic compounds. These gases act as precursors to secondary particulates and ozone $\left(\mathrm{O}_{3}\right)$. Besides its health impacts, black carbon (BC) is recognized as the second most important climate forcing agent (Bond et al., 2013). In Bengaluru, few studies have reported ambient $\mathrm{PM}_{2.5}$ (Both et al., 2011; Gouda et al., 2021; Sreekanth et al., 2021) and BC (Babu et al., 2002; Satheesh et al., 2011), based on short-term and long-term observation campaigns. In Urban Bengaluru and surrounding regions, Vreeland et al. (2016) reported high organic carbon (OC) to elemental carbon (EC) ratios (OC/EC values as high as 1500) for trash-burning emissions compared to that of the ambient atmosphere.

In the present study, in addition to reporting the temporal variations in $\mathrm{PM}_{2.5}, \mathrm{BC}$, and $\mathrm{O}_{3}$, results obtained by the application of statistical techniques on the time series data to identify the potential source locations are also presented. Local-regional and fossil fuel-biomass burning contributions to the observed $\mathrm{BC}$ are also investigated. Finally, the health impacts (long term) due to long-term $\mathrm{PM}_{2.5}$ exposure are studied using the AirQ+software developed by the World Health Organization (WHO, 2018).

\section{Materials and methods}

Study site

Simultaneous measurements of ambient $\mathrm{PM}_{2.5}, \mathrm{BC}$, and $\mathrm{O}_{3}$ were carried out for a period of 1 year (July 2019 to June 2020) using reference-grade instrumentation installed on the terrace of the Center for Study of Science, Technology, and Policy (CSTEP) building. The sampling height was $\sim 10 \mathrm{~m}$ above ground level and $\sim 150 \mathrm{~m}$ away from the main road. CSTEP $\left(13.04^{\circ} \mathrm{N} ; 77.57^{\circ} \mathrm{E}\right)$ is located in the northern part of Bengaluru. The city of Bengaluru is the capital of Karnataka, with a population of around 12.7 million in 2021 (www.macrotrends.net). Bengaluru Urban observed rapid growth in terms of urbanization and population density during the last two decades (a $46.7 \%$ growth rate in population during 2001-2011 as per Census 2011). Consequently, the city has been experiencing a vast increase in the number of motor vehicles, especially two-wheelers. In terms of climate, Bengaluru's climate is classified as dry tropical Savanna type with an average maximum and minimum temperature of 36 and $14{ }^{\circ} \mathrm{C}$, respectively. Humidity ranges between 35 and $80 \%$ and the average total annual rainfall is $\sim 540 \mathrm{~mm}$ (Rajashekara, 2020). Bengaluru experiences four distinct seasons, namely, winter (December-February), summer (March-May), monsoon (June-September), and post-monsoon (October-November). The geographical location of the measurement site is shown in Fig. 1. 


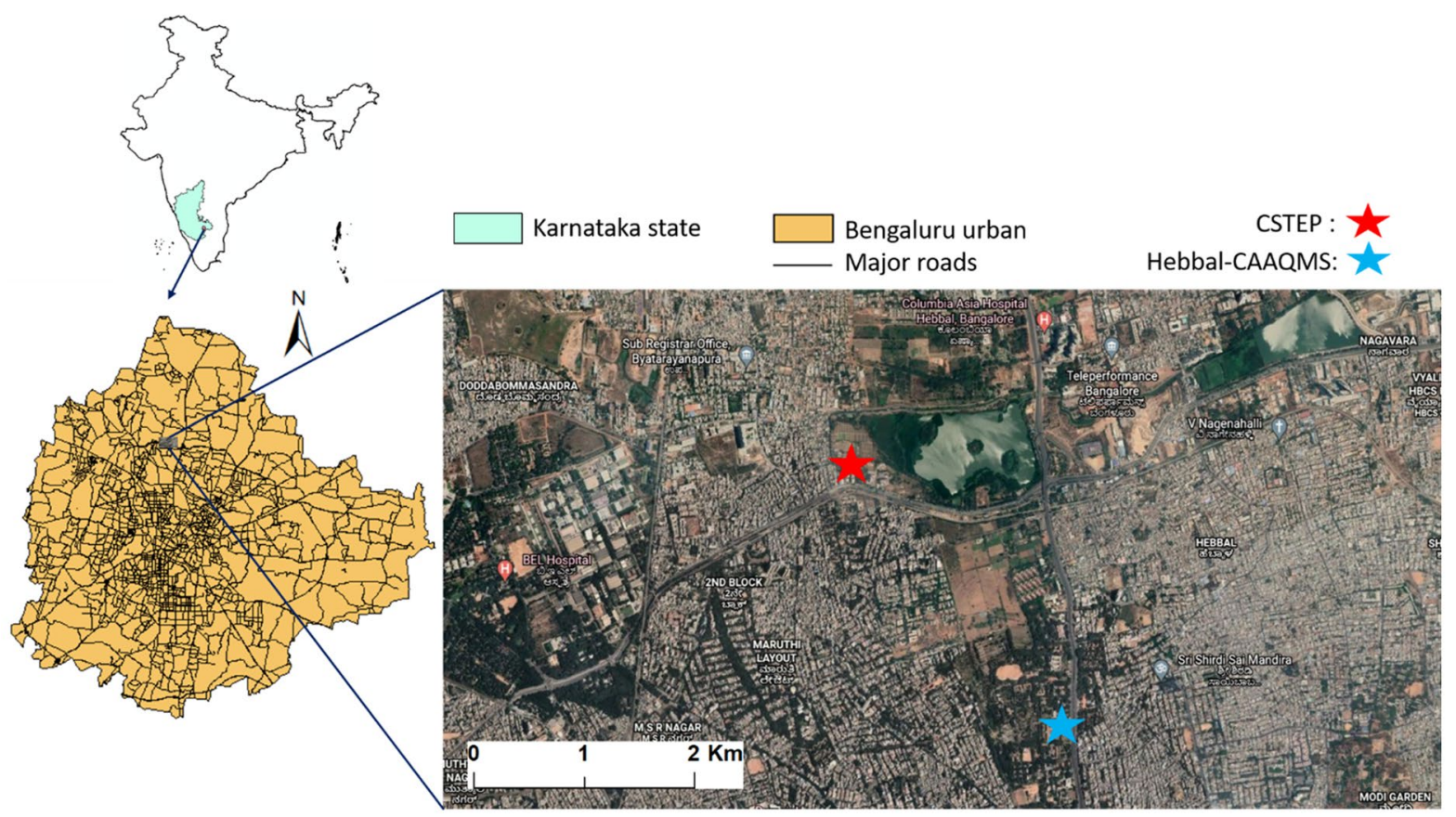

Fig. 1 Map showing the locations of CSTEP (red star) and Hebbal-CAAQMS (blue star)

Instrumentation

$P M_{2.5}$

Near-real-time $\mathrm{PM}_{2.5}$ was measured using a Beta Attenuation Monitor (BAM-1022, Met One Instruments, Grants Pass, USA). As the name suggests, the instrument utilizes the beta attenuation technique to quantify $\mathrm{PM}_{2.5}$. The difference in the beta particle (source: $\mathrm{C}^{14}$ ) attenuation before and after the aerosol sample deposition on the filter tape is converted into $\mathrm{PM}_{2.5}$ using Beer-Lambert's law. The flow rate of the instrument is 16.7 LPM. An inbuilt heating arrangement controls the humidity of the sampled air. The detection limit of the BAM1022 is $<1 \mu \mathrm{g} \mathrm{m}^{-3}(24 \mathrm{~h})$, and the span measurement ranges from -15 to $10^{4} \mu \mathrm{g} \mathrm{m}^{-3}$. BAM-1022 is a United States Environmental Protection Agency (USEPA)-certified federal equivalent method (FEM) class instrument. Periodical flow calibration of BAM-1022 was performed using a volumetric flow calibrator (The BGI deltaCal, Mesa Labs, Lakewood, USA).
$B C$

A rack mount Aethalometer (AE33, Aerosol d.o.o. Ljubljani, Slovenia) was used for measuring absorbing aerosol mass concentration at seven wavelengths (370, 470, 520, 590, 660, 880, and $950 \mathrm{~nm})$. The instrument measures the optical absorption of the aerosol sample collected on the filter tape and converts it into mass concentrations using factory calibration coefficients. The absorbing mass concentration estimated at $880 \mathrm{~nm}$ was considered as BC (or equivalent $\mathrm{BC})$. The dual spot technology incorporated in AE33 compensates for the filter loading artifact. At CSTEP, the aethalometer was operated with a $2.5-\mu \mathrm{m}$ size cut cyclone and rain/insect guard, and at a flow rate of $2 \mathrm{~L}$ per min (LPM). The data averaging and logging interval was set to 1-min time duration. Using the spectral measurements, $\mathrm{AE} 33$ apportions the total $\mathrm{BC}$ into fossil fuel $\left(\mathrm{BC}_{\mathrm{ff}}\right)$ and biomass burning $\left(\mathrm{BC}_{\mathrm{bb}}\right)$ contributed mass concentrations. Stability and zero checks of AE33 were performed on a monthly basis. A detailed description of the instrument and its working principle can be found in Drinovec et al. (2015). 
$\mathrm{O}_{3}$

The surface $\mathrm{O}_{3}$ was measured using a dual-beam ozone monitor (205 Dual Beam Ozone Monitor, 2B Technologies, Boulder USA). This monitor works on the principle of UV (254 nm) absorption to quantify ozone with a dynamic range of 0-250 ppm. The accuracy of the $\mathrm{O}_{3}$ measurements is greater of $1 \mathrm{ppb}$ or $2 \%$ of the measurement. The measurement resolution is $0.1 \mathrm{ppb}$. The nominal flow rate of the instrument is $\sim 1.8$ LPM. The Model 205 Ozone monitor was designated as a FEM instrument by USEPA. The instrument was configured to log the data at 1-min averaging intervals. A portable ozone calibration source (Model 306 Ozone Calibration Source, 2B Technologies) was used to calibrate the ozone monitor periodically.

\section{Meteorological parameters}

One-minute averaged data on ambient meteorological variables was collected using a Davis weather station (Vantage Pro2, Davis Instruments Corporation, Hayward, USA). The weather station includes a cup and vane anemometer (for the measurement of wind speed and direction), rain collector, temperature, and humidity sensors.

\section{Pollution control board (PCB) data}

Public data on $\mathrm{PM}_{2.5}$ and $\mathrm{O}_{3}$ from the Continuous Ambient Air Quality Monitoring Stations (CAAQMS) installed in Bengaluru were also used for comparative analysis. Data on gaseous pollutants from Hebbal CAAQMS was included to perform principal component analysis. CAAQMS data was downloaded from the CPCB dashboard (https:// app.cpcbccr.com/ccr/\#/caaqm-dashboard-all/caaqmlanding/data). As these datasets are used for regulatory purposes, reference-grade instruments were used to measure the pollution levels. A thorough check on the data quality was conducted using the "pollucheck" application (Upadhya et al., 2021). The quality check criteria included the removal of outliers and impractical values. The amount of data labeled as spurious and subsequently removed was $<2 \%$ of the total.
Statistical tools and techniques

\section{Principal component analysis}

The principal component analysis (PCA) is a simple tool to visualize the total variation of the variables in a reduced number of dimensions. PCA is most commonly used in air pollution research to identify the critical pollutants, their sources, and the association between environmental variables and pollutants (e.g., Banerjee et al., 2015). For performing PCA, the minimum number of samples $(n)$ required is based on the condition $n>30+\{(X+3) / 2\}$, where $X$ is the number of variables (Henry et al., 1984). In the present study, temperature, relative humidity $(\mathrm{RH}), \mathrm{BC}_{\mathrm{bb}}, \mathrm{BC}_{\mathrm{ff}}, \mathrm{O}_{3}, \mathrm{PM}_{2.5}, \mathrm{NO}_{2}$, $\mathrm{NH}_{3}, \mathrm{SO}_{2}$, and $\mathrm{CO}$ were considered as the variables for PCA. The principal components were identified using varimax rotation with Kaiser normalization. Eigenvalue of $>1$ was the criterion for considering the principal components, and a loading value of 0.7 was chosen as the minimum level of significance for variables under each principal component (Sarkar \& Khillare, 2013; Nirmalkar et al., 2015). PCA was performed using the R package "psych" (Revelle, 2016).

\section{Local and regional contribution}

To investigate the contribution of local $(<0.5 \mathrm{~km}$ radius region) and regional sources to the observed BC, we applied a successive moving average subtraction technique proposed by Watson and Chow (2001). As this methodology demands high temporal resolution measurements, in this study, it was applied only to $\mathrm{BC}$ measurements (made at one-minute averaging and logging intervals). To date, this technique has been applied on $\mathrm{PM}_{2.5}$ (Apte et al., 2011; Both et al., 2011; Kumar et al., 2018) only. In this approach, the 1-min average $\mathrm{BC}$ values are smoothed at multiple timescales (360 min, $180 \mathrm{~min}, 90 \mathrm{~min}, 45 \mathrm{~min}$, and $15 \mathrm{~min}$ ), always retaining the lowest values. Smoothed concentrations after removing the shortduration spikes were interpreted as regional (and long-range transported) share.

\section{Conditional bivariate probability function (CBPF)}

To identify the potential local source regions of $\mathrm{BC}$ and $\mathrm{PM}_{2.5}$, the CBPF technique was employed. The 
CBPF is a receptor model (Uria-tellaetxe \& Carslaw, 2014) that can identify the emission source regions based on wind speed and wind direction. CBPF is an extension to conditional probability function (CPF), where a third variable (wind speed) is coupled with the CPF to identify and characterize the local sources. The CBPF was computed as shown below:

$C B P F_{\Delta \theta, \Delta \mathrm{u}}=\frac{m_{\Delta \theta,\left.\Delta \mathrm{u}\right|_{\mathrm{y} \geq \mathrm{c} \geq \mathrm{x}}}}{n_{\Delta \theta, \Delta \mathrm{u}}}$

where $m_{\Delta \theta, \Delta \mathrm{u}}$ is the number of samples within wind direction interval $\Delta \theta$ and wind speed interval $\Delta \mathrm{u}$, characterized with a pollution concentration $C$ between the interval $y$ and $x$. The $n_{\Delta \theta, \Delta \mathrm{u}}$ is the total number of samples in that specified wind speed and wind direction interval. CBPF was computed using the freely available R-package "openair".

\section{Concentration weighted trajectories $(C W T)$}

To identify the long-range transport pathways and the relative contribution of each spatial grid to the observed receptor site pollutant concentration level, 5-day isentropic air mass back trajectory analysis and CWT were performed, respectively. An altitude of $500 \mathrm{~m}$ above ground level was considered for the trajectory analysis. The TrajStat software (version 1.2.2.6) was used for performing the trajectory cluster analysis and CWT. The average weighted concentration in each grid was computed as shown below:

$C_{i j}=\frac{1}{\sum_{l=1}^{M} T_{i j l}} \sum_{l=1}^{M} C_{l} T_{i j l}$

where, $i, j$ are the grid indices, $l$ is the index of the trajectory, $\mathrm{C}_{l}$ is the concentration observed at sampling location (receptor site) on the arrival of trajectory $l, M$ is the total number of trajectories, and $T_{i j l}$ is the residence time (time spent) of the trajectory $l$ in the grid cell. A high value for $\mathrm{C}_{i j}$ implies that the air parcels traveling over the grid cell would be, on average, associated with high concentrations at the receptor site. A grid size of $0.5^{\circ}$ was chosen for the CWT analysis.

\section{Health risk assessment}

The health risk assessment due to long-term exposure to $\mathrm{PM}_{2.5}$ and $\mathrm{O}_{3}$ was estimated using AirQ + v.2.1.1 (WHO, 2018). Mortality due to all (natural) causes (age: 15+), acute lower respiratory illness (ALRI; age: $<5)$, chronic obstructive pulmonary disorder (COPD; age: 15+), lung cancer (LC; age: 15+), ischemic heart disease (IHD; age: $25+$ ), and stroke in adults (age: $25+$ ) were estimated using the 2019 annual $\mathrm{PM}_{2.5}$ derived by combining $\mathrm{PM}_{2.5}$ from CAAQMS stations and CSTEP data. For this analysis, the calendar year of 2019 was considered. The disease-specific baseline mortality rate for Karnataka state (for 2019) was adopted from Global Burden of Disease (GBD) India compare data visualization (ICMR, PHFI, \& IHME, 2019). The default relative risk (RR) values available in the AirQ + software for each health endpoint were retained for the analysis. The RR values in AirQ+were derived from HRAPIE (2013). Bengaluru population data for 2019 was obtained from population.com. Demographic data for India was obtained from the United Nations Department of Economic and Social Affairs (https://population.un.org), World Prospect Population 2019. The age group-specific population of Bengaluru was estimated assuming that the demography of the city is the same as that of India. The cutoff value of $\mathrm{PM}_{2.5}$ was considered as $2.4 \mu \mathrm{g} \mathrm{m}^{-3}$, according to the GBD 2015/2016 (Cohen et al., 2017).

\section{Results and discussion}

\section{Temporal variations}

The study period mean ( \pm standard deviation) of $\mathrm{PM}_{2.5}$ and $\mathrm{BC}$ are $26.8 \pm 11.5 \mu \mathrm{g} \mathrm{m}^{-3}$ and $5.6 \pm 2.8 \mu \mathrm{g} \mathrm{m}^{-3}$, respectively. $\mathrm{BC}$ data during monsoon is not available due to instrument malfunctioning, and the average mentioned here might be an overestimate of the annual mean. The observed $\mathrm{PM}_{2.5}$ mean was below the national annual permissible limit $\left(40 \mu \mathrm{g} \mathrm{m}^{-3}\right)$. However, the observed $\mathrm{PM}_{2.5}$ was $\sim 5.4$ times higher than the recent WHO annual standard $\left(5 \mu \mathrm{g} \mathrm{m}^{-3}\right)$. Seasonal mean $\mathrm{PM}_{2.5}$ was observed to be the highest in winter $\left(33.5 \pm 10.6 \mu \mathrm{g} \mathrm{m}^{-3}\right)$, followed by summer, postmonsoon, and monsoon (Fig. 2). The highest seasonal mean BC was observed for the post-monsoon season $\left(5.9 \pm 3.3 \mu \mathrm{g} \mathrm{m}^{-3}\right)$ (Table 1). The factors responsible for the observed seasonal pattern in PM were discussed in several earlier studies (e.g., Prabhu et al., 2020) and are not repeated here. Kruskal-Wallis test (nonparametric one-way ANOVA) revealed statistically 

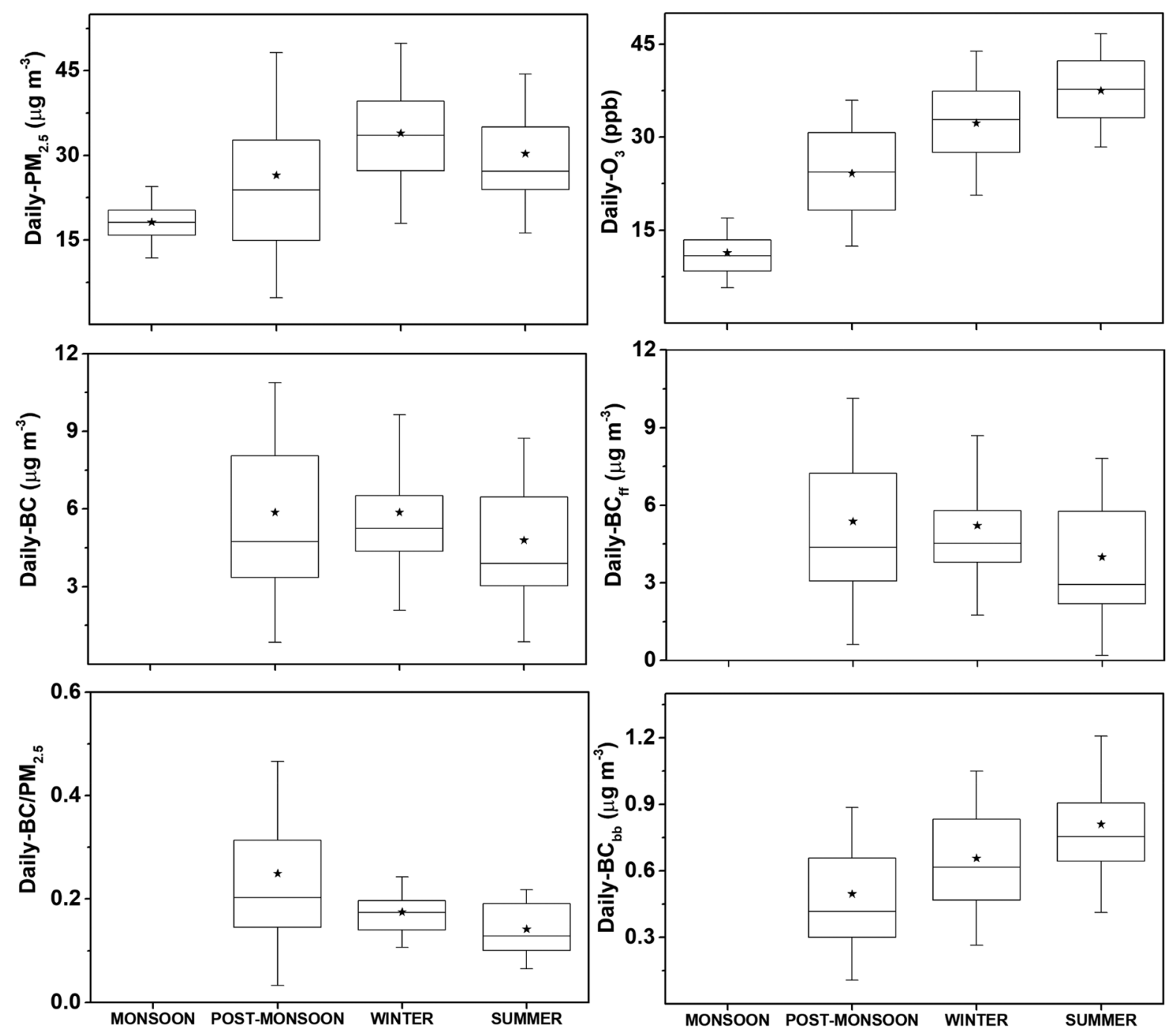

Fig. 2 Seasonal variations in daily- $\mathrm{PM}_{2.5}, \mathrm{BC}, \mathrm{BC} / \mathrm{PM}_{2.5}, \mathrm{O}_{3}, \mathrm{BC}_{\mathrm{ff}}$, and $\mathrm{BC}_{\mathrm{bb}}$. The 25 th and 75 th percentiles are represented by the box, the standard deviation is represented by whiskers, and the mean is represented by the solid star

significant $(p<0.05)$ differences in $\mathrm{PM}_{2.5}$ and $\mathrm{BC}$ levels across seasons. $\mathrm{PM}_{2.5}$ did not exhibit any significant weekday-weekend variations, while $\mathrm{BC}$ during weekdays was $\sim 10 \%$ (Fig. S1) higher than that on weekends.

On diurnal scales, $\mathrm{PM}_{2.5}$ and $\mathrm{BC}$ exhibited two peaks - a rush hour and a nocturnal peak (Fig. 3). Several investigators have attributed the diurnal variation to the combined effect of meteorological and anthropogenic activities (Babu et al., 2002; Soni et al., 2019). During the study period, $\mathrm{BC}_{\mathrm{ff}}$ contributed $\sim 88 \%$ to the observed total $\mathrm{BC}$. The seasonality in $\mathrm{BC}_{\mathrm{ff}}$ resembled that of the total $\mathrm{BC}$, while no seasonality was observed in $\mathrm{BC}_{\mathrm{bb}}$. The contribution of $\mathrm{BC}$ to $\mathrm{PM}_{2.5}$ was observed to be high during post-monsoon (25\%), followed by winter (17\%) and summer (14\%). The diurnal variation in the $\mathrm{BC} / \mathrm{PM}_{2.5}$ ratio revealed two peaks - one in the morning during 0500 to $0600 \mathrm{~h}$ and another in the evening during 1800 to $1900 \mathrm{~h}$.

The annual mean $\mathrm{O}_{3}$ was $25.5 \pm 12.4 \mathrm{ppb}$. The highest seasonal mean was observed for summer (37.4 $\pm 11.6 \mathrm{ppb})$, followed by winter $(31.0 \pm 7.8 \mathrm{ppb})$, post-monsoon $(24.1 \pm 7.8 \mathrm{ppb})$, and monsoon (11.3 $\pm 3.7 \mathrm{ppb})$. High $\mathrm{O}_{3}$ during summer can be attributed to the high intensity of solar radiation reaching the earth's surface, longer daylight hours, and higher surface temperatures enhancing photochemical $\mathrm{O}_{3}$ production (Peshin et al., 2017). The diurnal 
Table 1 Monthly, seasonal, and annual mean ( \pm standard deviation) of pollutants measured at CSTEP (NA denotes not available)

\begin{tabular}{|c|c|c|c|c|c|c|c|c|}
\hline $\begin{array}{l}\text { Month/sea- } \\
\text { son/annual }\end{array}$ & $\begin{array}{l}\mathrm{PM}_{2.5}(\mu \mathrm{g} \\
\left.\mathrm{m}^{-3}\right)\end{array}$ & $\mathrm{BC}\left(\mu \mathrm{g} \mathrm{m}^{-3}\right)$ & $\begin{array}{l}\mathrm{BC}_{\mathrm{ff}}(\mu \mathrm{g} \\
\left.\mathrm{m}^{-3}\right)\end{array}$ & $\begin{array}{l}\mathrm{BC}_{\mathrm{bb}}(\mu \mathrm{g} \\
\left.\mathrm{m}^{-3}\right)\end{array}$ & $\mathrm{O}_{3}(\mathrm{ppb})$ & $\begin{array}{l}\text { Temperature } \\
\left({ }^{\circ} \mathrm{C}\right)\end{array}$ & $\begin{array}{l}\text { Relative } \\
\text { humidity (\%) }\end{array}$ & $\begin{array}{l}\text { Wind speed } \\
\left(\mathrm{m} \mathrm{s}^{-1}\right)\end{array}$ \\
\hline JUL (2019) & $18.1 \pm 2.8$ & $N A$ & $N A$ & $N A$ & $11.6 \pm 1.8$ & $24.5 \pm 1.2$ & $70.9 \pm 17.9$ & $2.1 \pm 0.3$ \\
\hline AUG (2019) & $17.8 \pm 3.4$ & $N A$ & $N A$ & $N A$ & $9.0 \pm 1.9$ & $23.9 \pm 0.7$ & $77.7 \pm 5.3$ & $2.3 \pm 0.6$ \\
\hline SEP (2019) & $19.0 \pm 6.1$ & $N A$ & $N A$ & $N A$ & $10.5 \pm 4.5$ & $24.4 \pm 0.9$ & $78.0 \pm 5.2$ & $1.6 \pm 0.8$ \\
\hline OCT (2019) & $20.9 \pm 8.7$ & $6.4 \pm 3.4$ & $6.0 \pm 3.2$ & $0.4 \pm 0.2$ & $21.1 \pm 6.7$ & $24.1 \pm 1.0$ & $76.1 \pm 4.5$ & $0.9 \pm 0.4$ \\
\hline NOV (2019) & $32.3 \pm 16.9$ & $5.3 \pm 3.3$ & $4.7 \pm 3.0$ & $0.6 \pm 0.9$ & $26.8 \pm 7.8$ & $23.9 \pm 1.1$ & $67.8 \pm 6.3$ & $1.0 \pm 0.4$ \\
\hline DEC (2019) & $29.8 \pm 10.8$ & $4.6 \pm 1.7$ & $4.1 \pm 1.2$ & $0.4 \pm 0.1$ & $27.2 \pm 5.3$ & $22.1 \pm 0.7$ & $68.4 \pm 5.9$ & $1.4 \pm 0.3$ \\
\hline JAN (2020) & $36.4 \pm 12.4$ & $7.4 \pm 3.3$ & $6.7 \pm 3.0$ & $0.7 \pm 0.3$ & $30.7 \pm 7.3$ & $22.4 \pm 1.2$ & $54.4 \pm 8.6$ & $1.0 \pm 0.5$ \\
\hline FEB (2020) & $35.5 \pm 6.7$ & $5.6 \pm 1.7$ & $4.9 \pm 1.6$ & $0.7 \pm 0.2$ & $38.2 \pm 6.2$ & $24.5 \pm 0.8$ & $47.8 \pm 5.8$ & $1.4 \pm 0.4$ \\
\hline MAR (2020) & $35.4 \pm 10.5$ & $5.8 \pm 3.0$ & $5.1 \pm 2.9$ & $0.7 \pm 0.2$ & $37.0 \pm 4.8$ & $26.0 \pm 0.9$ & $50.9 \pm 3.2$ & $0.9 \pm 0.5$ \\
\hline APR (2020) & $29.8 \pm 8.9$ & $3.4 \pm 0.8$ & $2.5 \pm 0.6$ & $0.9 \pm 0.3$ & $40.3 \pm 6.3$ & $N A$ & $N A$ & $N A$ \\
\hline MAY (2020) & $25.6 \pm 5.4$ & $N A$ & $N A$ & $N A$ & $36.4 \pm 6.6$ & $N A$ & $N A$ & $N A$ \\
\hline JUN (2020) & $17.7 \pm 3.6$ & $N A$ & $N A$ & $N A$ & $14.4 \pm 2.8$ & $N A$ & $N A$ & $N A$ \\
\hline MONSOON & $18.2 \pm 4.2$ & $N A$ & $N A$ & $N A$ & $11.3 \pm 3.7$ & $24.2 \pm 0.9$ & $75.1 \pm 10.1$ & $2.0 \pm 0.7$ \\
\hline $\begin{array}{l}\text { POST-MON- } \\
\text { SOON }\end{array}$ & $26.5 \pm 14.5$ & $5.9 \pm 3.3$ & $5.6 \pm 3.2$ & $0.5 \pm 0.3$ & $24.1 \pm 7.8$ & $24.1 \pm 1.1$ & $72.0 \pm 6.8$ & $1.0 \pm 0.4$ \\
\hline WINTER & $33.5 \pm 10.6$ & $5.7 \pm 2.5$ & $5.1 \pm 2.3$ & $0.6 \pm 0.3$ & $31.0 \pm 7.8$ & $23.4 \pm 1.3$ & $59.7 \pm 11.0$ & $1.2 \pm 0.4$ \\
\hline SUMMER & $30.2 \pm 9.9$ & $4.8 \pm 2.6$ & $4.0 \pm 2.5$ & $0.8 \pm 0.3$ & $37.4 \pm 11.6$ & $26.1 \pm 0.9$ & $51.2 \pm 3.2$ & $0.7 \pm 0.5$ \\
\hline ANNUAL & $26.8 \pm 11.5$ & $5.6 \pm 2.8$ & $4.9 \pm 2.7$ & $0.6 \pm 0.3$ & $25.5 \pm 12.4$ & $23.8 \pm 1.2$ & $66.9 \pm 12.8$ & $1.4 \pm 0.7$ \\
\hline
\end{tabular}

pattern of $\mathrm{O}_{3}$ indicated higher levels during the afternoon, reaching its peak value at $\sim 1400 \mathrm{~h}$. The $\mathrm{O}_{3}$ builds up after sunrise, coinciding with the increasing solar radiation (Mahapatra et al., 2012). The diurnal variation in PM and $\mathrm{O}_{3}$ observed the opposite pattern.

\section{$\mathrm{O}_{3}$ versus particulate matter}

Relationships between $\mathrm{O}_{3}$ and fine PM at hourly and daily scales were investigated. Figure 4 indicates a negative correlation between $\mathrm{O}_{3}$ and $\mathrm{BC}$ (a similar relationship is observed between $\mathrm{O}_{3}$ and $\mathrm{BC}_{\mathrm{ff}}$ ). Grossly, a $1 \mu \mathrm{g} \mathrm{m}^{-3}$ increase in hourly $\mathrm{BC}_{\mathrm{ff}}$ was associated with a reduction of $\sim 1.8$ ppb of hourly $\mathrm{O}_{3}(p<0.05)$, while a $1 \mu \mathrm{g} \mathrm{m}^{-3}$ increase in daily $\mathrm{BC}_{\mathrm{ff}}$ was associated with a reduction of $\sim 0.5 \mathrm{ppb}$ of daily $\mathrm{O}_{3}(p<0.05)$. A similar observation was reported in Hyderabad city, where every $1 \mu \mathrm{g} \mathrm{m}^{-3}$ increase in $\mathrm{BC}$ causes a reduction of $\sim 3.5 \mu \mathrm{g} \mathrm{m}^{-3}$ of $\mathrm{O}_{3}$ (Latha \& Badarinath, 2004). Generally, soot exhibits a large surface for heterogeneous interactions and chemical transformations of atmospheric constituents, especially for $\mathrm{O}_{3}$ and $\mathrm{NO}_{x}$ (Lary et al., 1997; Monge et al., 2010). Major sources of $\mathrm{BC}_{\mathrm{ff}}$ being vehicular and industrial emissions, $\mathrm{NO}_{\mathrm{x}}, \mathrm{CO}$, and
VOCs, are co-emitters. These gases undergo a series of complex non-linear and sunlight-driven reactions, which either enhance or deplete the surface ozone abundance in the atmosphere. We observed an overall weak positive correlation between $\mathrm{O}_{3}$ and $\mathrm{PM}_{2.5}$ on an hourly and daily basis. Grossly, a $1 \mu \mathrm{g} \mathrm{m}^{-3}$ increase in hourly $\mathrm{PM}_{2.5}$ was associated with an increase of $\sim 0.2 \mathrm{ppb}$ of hourly $\mathrm{O}_{3}(p<0.05)$, while a $1 \mu \mathrm{g} \mathrm{m}^{-3}$ increase in daily $\mathrm{PM}_{2.5}$ was associated with an increase of $\sim 0.6 \mathrm{ppb}$ of daily $\mathrm{O}_{3}(p<0.05)$. Given the contrasting underlying mechanisms driving the relationship between $\mathrm{O}_{3}$ and $\mathrm{PM}_{2.5}$ during cold and hot seasons (e.g., Jia et al., 2017), we investigated seasonal relationships. No significant difference was observed in the $\mathrm{O}_{3}$ and fine $\mathrm{PM}$ relationships across the summer and winter seasons. The slope and $R^{2}$ were almost the same during winter and summer (Figs. S3 and S4). This could be partially due to the observed shallow gradients in temperature (and sunlight) across the seasons over the study location. The mean temperature during winter and summer was observed to be $\sim 2{ }^{\circ} \mathrm{C}$ during the study period. The correlations observed here are weak but were statistically significant. 

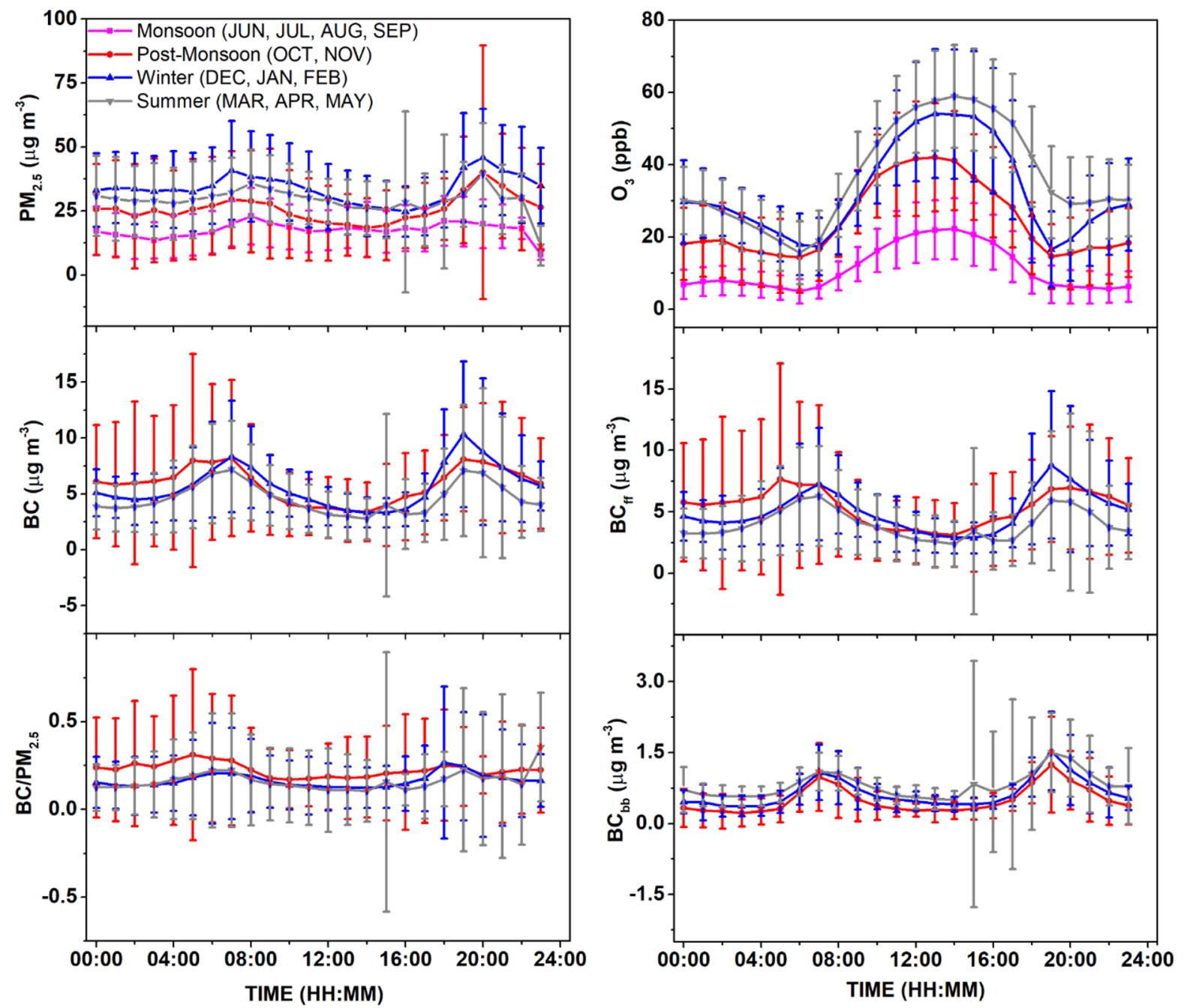

Fig. 3 Seasonal diurnal variation in $\mathrm{PM}_{2.5}, \mathrm{BC}, \mathrm{BC}$ to $\mathrm{PM}_{2.5}$ ratio, $\mathrm{O}_{3}, \mathrm{BC}_{\mathrm{ff}}$, and $\mathrm{BC}_{\mathrm{bb}}$

Comparison with CAAQMS data

In this section, we compared the CSTEP-measured $\mathrm{PM}_{2.5}$ and $\mathrm{O}_{3}$ data with that of the publicly available CAAQMS regulatory measurements (Fig. 5). $\mathrm{PM}_{2.5}$ data from eight CAAQMS stations were available during the study period, while $\mathrm{O}_{3}$ was available for seven stations. Annual distributions of daily mean pollutant values are shown in Fig. 5. The color of the box (in Fig. 5) indicates the different land-use types of the monitoring locations. Weak spatial variation in $\mathrm{PM}_{2.5}$ was observed across locations within Bengaluru. The central tendencies (mean and median) of the $\mathrm{PM}_{2.5}$ distributions for kerbside and residential locations were almost the same (mean: $\sim 26 \mu \mathrm{g} \mathrm{m}^{-3}$ ), while the industrial locations (Peenya and BWSSB) observed higher values $\left(\sim 37 \mu \mathrm{g} \mathrm{m}^{-3}\right)$ (see Table 2 for more details). The differences in the daily $\mathrm{PM}_{2.5}$ values across residential and kerbside locations were statistically nonsignificant. Seasonal variations indicated the maximum concentrations during winter in all the sites (except over Bapuji Nagar and BTM layout, which showed the maximum concentration during post-monsoon). Seasonal differences in daily $\mathrm{PM}_{2.5}$ were found to be statistically significant $(p<0.05)$. Similarly, the central tendencies of the daily mean $\mathrm{O}_{3}$ distribution for kerbside and residential locations were almost the same $\left(\sim 36 \mu \mathrm{g} \mathrm{m}^{-3}\right)$, while the BWSSB industrial location 

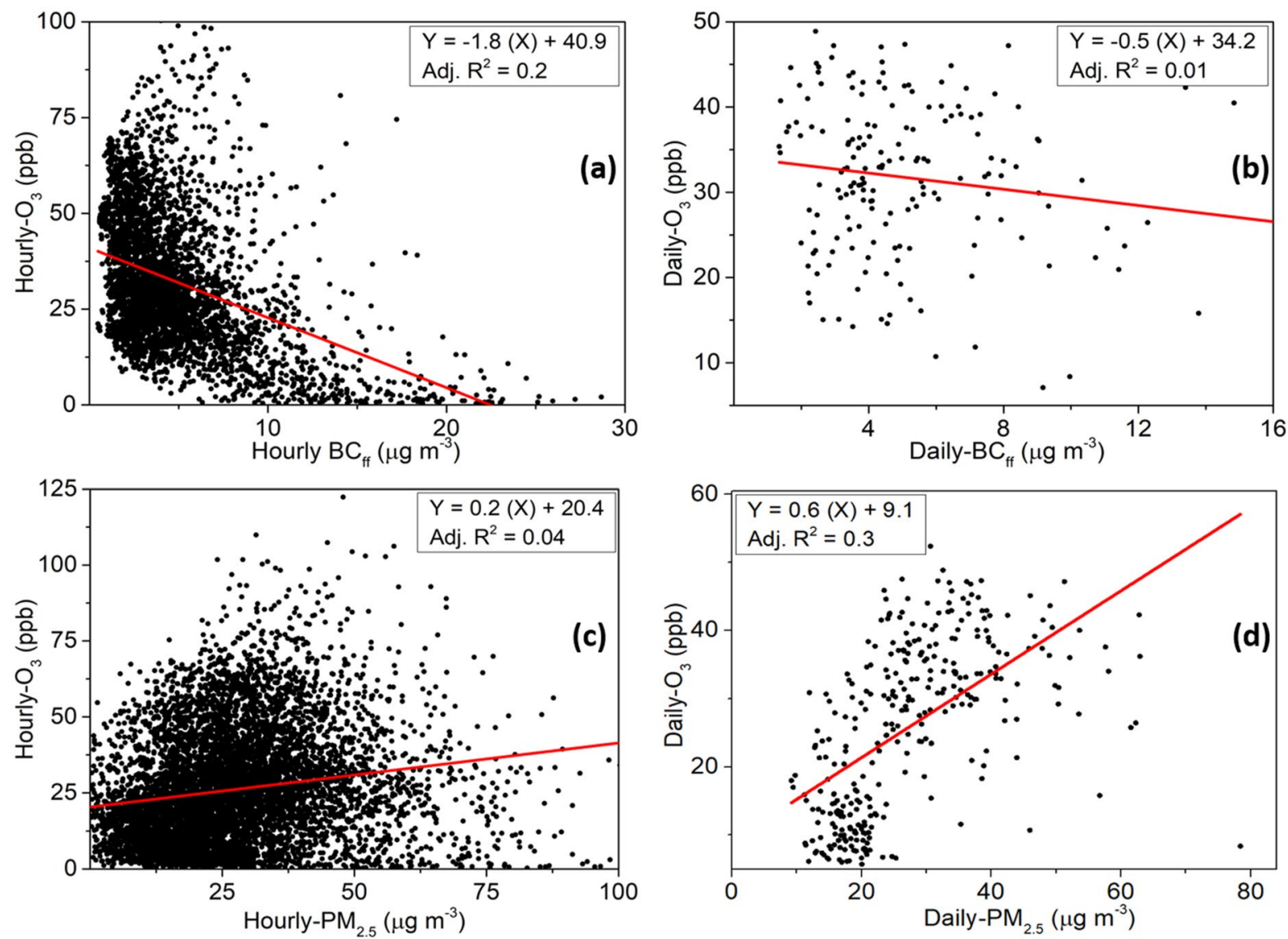

Fig. 4 Association between $\mathrm{O}_{3}$ and fine particulate matter. The red line indicates the linear least-square fit

observed lower values $\left(\sim 18 \mu \mathrm{g} \mathrm{m}^{-3}\right)$. CSTEP $\mathrm{O}_{3}$ data was converted from ppb to $\mu \mathrm{g} \mathrm{m}^{-3}$ for this comparison (considering the relation $1 \mathrm{ppb}=1.97 \mu \mathrm{g} \mathrm{m}^{-3}$ ). $\mathrm{O}_{3}$ data for the Peenya industrial site was not available during the study period. Again, differences in the daily $\mathrm{O}_{3}$ values across residential and kerbside locations were statistically non-significant. Seasonal variation revealed maximum $\mathrm{O}_{3}$ concentrations during summer (Table 2) in all the sites (except over Hombe Gowda, which showed the maximum concentration during winter). Seasonal differences in daily $\mathrm{O}_{3}$ were found to be statistically significant $(p<0.05)$.

\section{$P C A$}

We used hourly averaged pollution data for performing the PCA analysis. For this exercise, we combined data (temperature, $\mathrm{RH}, \mathrm{BC}_{\mathrm{bb}}, \mathrm{BC}_{\mathrm{ff}}, \mathrm{O}_{3}$, and $\mathrm{PM}_{2.5}$ ) collected at CSTEP, and other pollutant data $\left(\mathrm{NO}_{2}, \mathrm{NH}_{3}, \mathrm{SO}_{2}\right.$, and $\mathrm{CO}$ ) from the nearest CAAQMS (Hebbal; 2.2 km aerial distance from CSTEP, Fig. 1). Before performing PCA, we compared the common pollutant measurements $\left(\mathrm{PM}_{2.5}\right.$ and $\left.\mathrm{O}_{3}\right)$ from both the locations (CSTEP and Hebbal) and found that they are highly correlated (Fig. S2, Pearson's $R=>0.7$ ). The results of PCA analysis revealed that a cumulative variance of the data of $76 \%$ is associated with four principal components. Details of the four principal components, eigenvalues, and the cumulative variance are provided in Table 3. PC-1 (first principal component) accounted for $26 \%$ of the total data variance. The variables with a loading value greater than 0.7 in PC- 1 include $\mathrm{O}_{3}$ and temperature (positively correlated). This denotes the sunlight-driven formation of $\mathrm{O}_{3}$ in the atmosphere. PC-2 includes $\mathrm{PM}_{2.5}, \mathrm{BC}_{\mathrm{ff}}$, and $\mathrm{BC}_{\mathrm{bb}}$. This component signifies anthropogenic and combustion-related emissions. The PC-3 indicates the role of fuel combustion (including vehicular emissions) contribution towards 

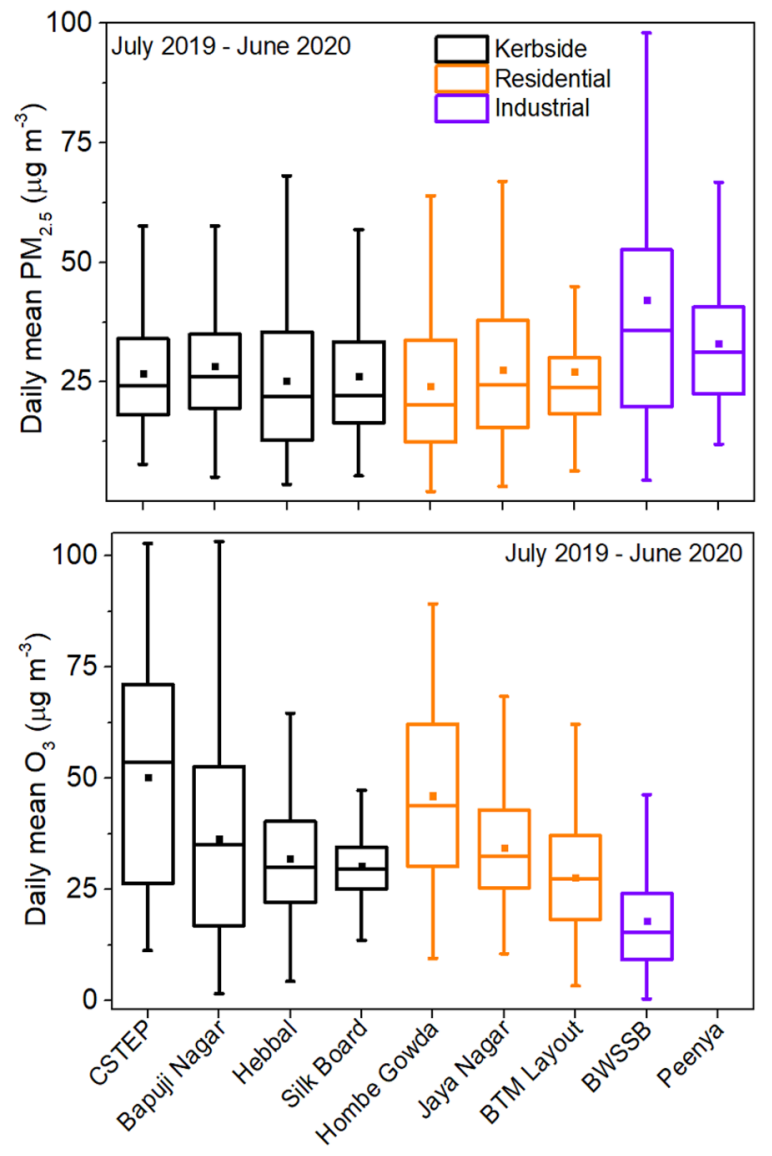

Fig. 5 Comparison of daily mean $\mathrm{PM}_{2.5}$ and $\mathrm{O}_{3}$ across CSTEP and PCB sites

the covariance in $\mathrm{CO}$ and $\mathrm{NO}_{2}$ (Mohammad et al., 2015). The PC-4 denotes the $\mathrm{SO}_{2}$ pollution, which can be from coal-burning activities. Similar principal components were also observed in earlier studies (Singh \& Sharma, 2012; Mallik et al., 2014; Saxena et al., 2016; Kumari et al., 2018).

Local and regional BC

For temporal decomposition of the real-time $\mathrm{BC}$, the successive moving average subtraction technique was employed, which segregated the absolute BC into local and regional components. From the analysis, the study period mean local and regional BC was observed to be $1.3 \pm 0.9$ and $4.2 \pm 1.9 \mu \mathrm{g} \mathrm{m}^{-3}$, respectively (Figs. 6, S5 and S6). This shows that around $78 \%$ share of $\mathrm{BC}$ was from the regional contribution ( $>0.5 \mathrm{~km}$ radius). Given the urban nature of the study

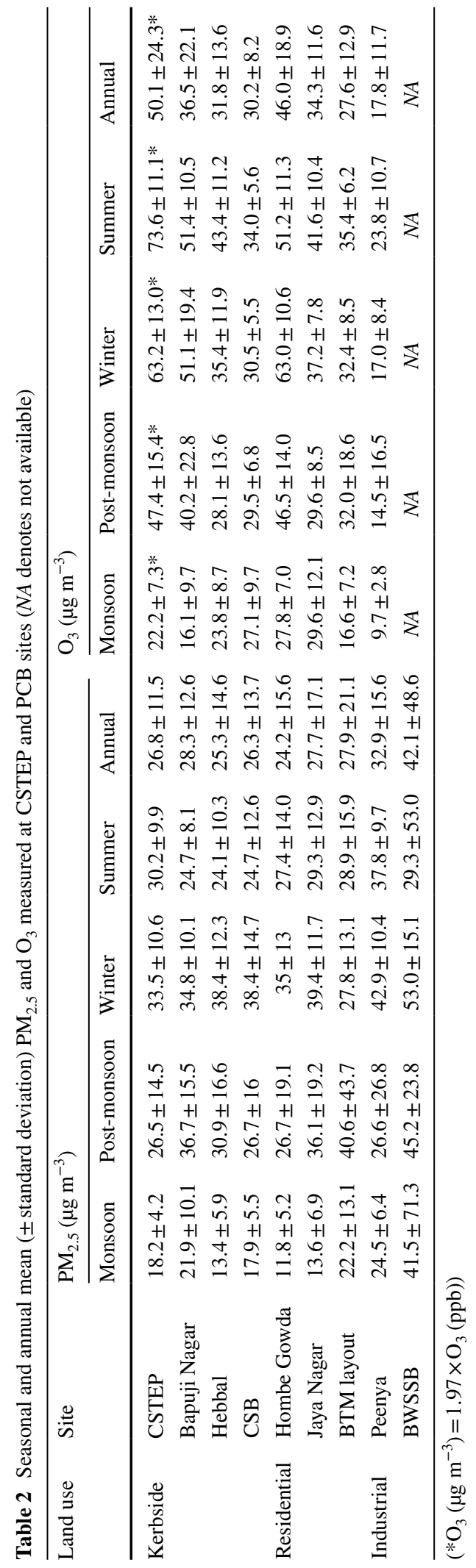


Table 3 Results of varimax rotated factor analysis

\begin{tabular}{lrrrr}
\hline Variable & \multicolumn{4}{l}{ Component } \\
& \multicolumn{1}{c}{ PC-1 } & \multicolumn{1}{c}{ PC-2 } & \multicolumn{1}{c}{ PC-3 } & \multicolumn{1}{c}{ PC-4 } \\
\hline Temperature & $\mathbf{0 . 8 5}$ & -0.07 & 0.14 & -0.04 \\
$\mathrm{RH}$ & -0.92 & -0.11 & -0.14 & -0.02 \\
$\mathrm{BC}_{\mathrm{bb}}$ & 0.08 & $\mathbf{0 . 7 6}$ & 0.45 & -0.06 \\
$\mathrm{BC}_{\mathrm{ff}}$ & -0.21 & $\mathbf{0 . 7 9}$ & 0.29 & 0.04 \\
$\mathrm{O}_{3}$ & $\mathbf{0 . 8 0}$ & -0.11 & -0.38 & 0.10 \\
$\mathrm{PM}_{2.5}$ & 0.06 & $\mathbf{0 . 8 7}$ & -0.06 & 0.24 \\
$\mathrm{NO}_{2}$ & -0.01 & 0.12 & $\mathbf{0 . 8 3}$ & 0.33 \\
$\mathrm{NH}_{3}$ & -0.47 & 0.05 & 0.09 & 0.64 \\
$\mathrm{SO}_{2}$ & 0.22 & 0.12 & 0.05 & $\mathbf{0 . 7 4}$ \\
$\mathrm{CO}$ & 0.04 & 0.23 & $\mathbf{0 . 8 1}$ & -0.09 \\
Eigenvalue & 2.9 & 2.5 & 1.1 & 1.0 \\
Cumulative variance & 25.5 & 46.3 & 64.4 & 75.9 \\
\hline
\end{tabular}

(Factor loading $>0.7$ are highlighted in bold) city (spread over $740 \mathrm{~km}^{2}$ ), BC pollution from other parts of the city and long-range transported components can have a greater influence on the observed concentrations. Similar analysis over different parts of the city can help us understand the spatial variation in the local component. The contribution of local $\mathrm{BC}$ to the absolute $\mathrm{BC}$ was minimum during February $(\sim 20 \%)$, while the maximum was observed during October $(\sim 30 \%)$. Seasonally, the contribution was maximum $(\sim 25 \%)$ during post-monsoon, while it is comparable between winter and summer ( 20\%).

Moreover, the successive moving average subtraction technique was employed to segregate absolute $\mathrm{BC}_{\mathrm{bb}}$ into local and regional components. Analysis revealed the mean daily local and regional $\mathrm{BC}_{\mathrm{bb}}$ as $0.2 \pm 0.1$ and $0.4 \pm 0.2 \mu \mathrm{g} \mathrm{m}^{-3}$, respectively. This shows that around $62 \%$ share of $\mathrm{BC}_{\mathrm{bb}}$ was from the regional contribution. The contribution of local- $\mathrm{BC}_{\mathrm{bb}}$ to the absolute $\mathrm{BC}_{\mathrm{bb}}$ was minimum during March $(\sim 30 \%)$, while the maximum was observed during

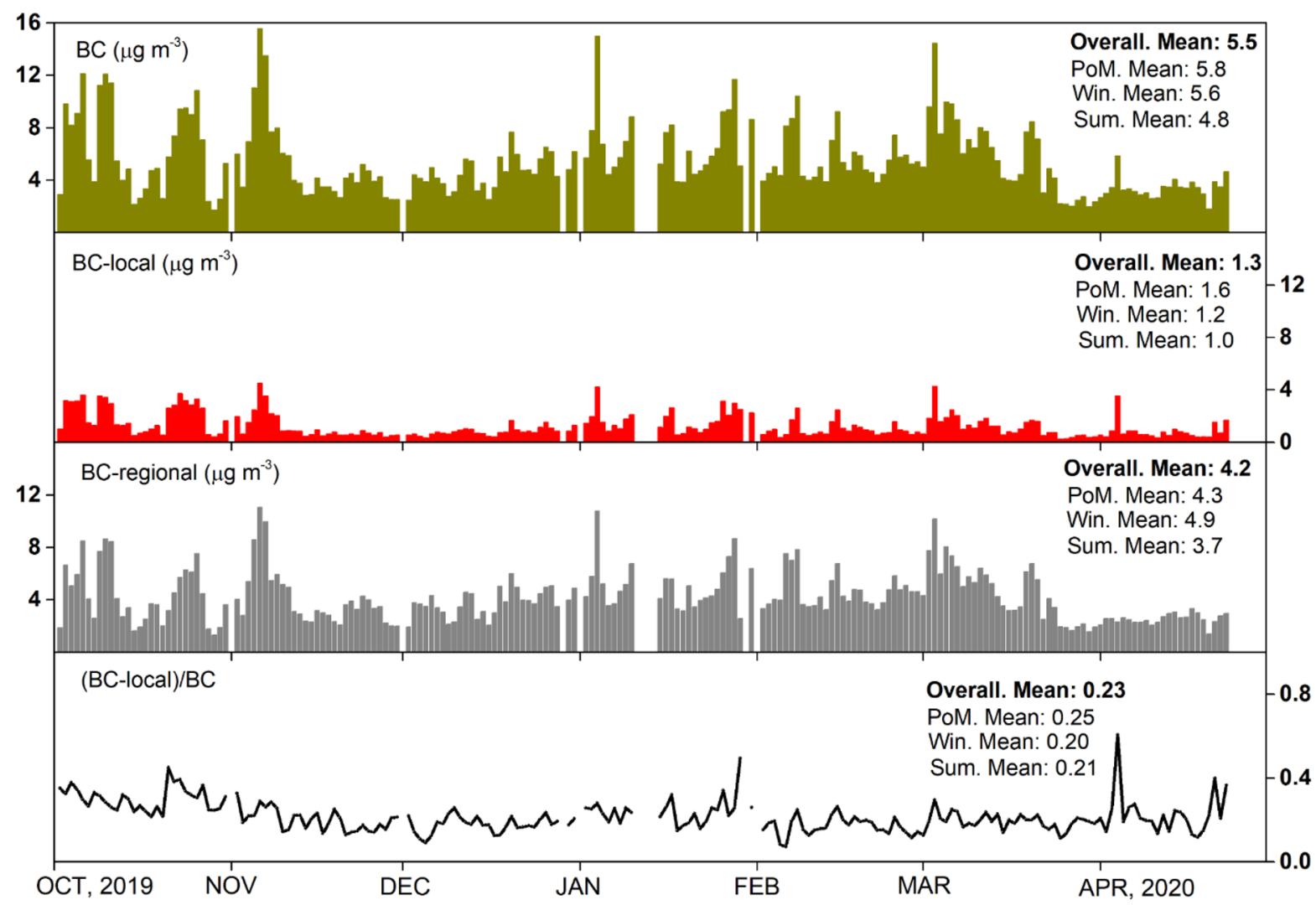

Fig. 6 Panel plot presenting the temporal variations in daily mean BC, BC-local, BC-regional, and BC-local/BC (PoM denotes postmonsoon; Win. denotes winter; Sum. denotes summer) 
October $(\sim 51 \%)$. Seasonally, the local contribution was maximum ( $46 \%)$ during post-monsoon, while it is comparable between winter and summer $(\sim 34 \%)$. Similarly, the mean daily local and regional $\mathrm{BC}_{\mathrm{ff}}$ was observed as $1.0 \pm 0.8$, and $3.8 \pm 1.8 \mu \mathrm{g} \mathrm{m}^{-3}$, respectively. This shows that around $76 \%$ share of $\mathrm{BC}_{\mathrm{ff}}$ was from the regional contribution. Local- $\mathrm{BC}_{\mathrm{ff}}$ contribution to the observed total $\mathrm{BC}_{\mathrm{ff}}$ was minimum during February $(\sim 15 \%)$, while the maximum was observed during October $(\sim 30 \%)$. Seasonally, the contribution was maximum ( $23 \%)$ during post-monsoon, while it is comparable between winter and summer $(\sim 17 \%)$.

\section{$C B P F$}

The CBPF analysis for $\mathrm{BC}, \mathrm{BC}_{\mathrm{ff}}$, and $\mathrm{BC}_{\mathrm{bb}}$ was performed using 1-min averaged values, while $\mathrm{CBPF}$ for $\mathrm{PM}_{2.5}$ was performed using hourly averaged values. The CBPF results were presented for concentrations in the percentile range of 50 and 98 (Fig. 7). The number of data points available for CBPF analysis of $\mathrm{PM}_{2.5}$ and $\mathrm{BC}$ were $\sim 8000$ and $\sim 200,000$, respectively. From Fig. 7, it can be noticed that the directions of the potential source regions contributing to the receptor site $\mathrm{PM}_{2.5}$ and $\mathrm{BC}$ are different. Sources potentially contributing to $\mathrm{PM}_{2.5}$ were located in the north and northwestern directions (coinciding with dense residential and commercial settlements) to the monitoring site. For BC, sources were towards the east and southeastern directions. A few isolated sources are observed for $\mathrm{BC}$, while for $\mathrm{PM}_{2.5}$, the

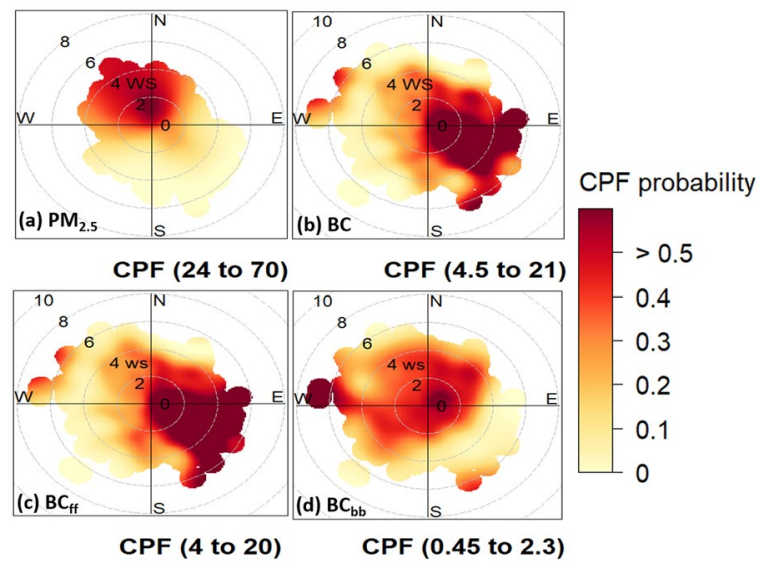

Fig. $7 \mathrm{CBPF}$ analysis of: (a) $\mathrm{PM}_{2.5}$, (b) $\mathrm{BC}$, (c) $\mathrm{BC}_{\mathrm{ff}}$, and (d) $\mathrm{BC}_{\mathrm{bb}}$. The wind speed is presented in $\mathrm{m} \mathrm{s}^{-1}$ sources were spread over a larger area. The $\mathrm{BC}$ and $\mathrm{BC}_{\mathrm{ff}}$ source directions and locations were almost similar. They were observed to coincide with that of traffic junctions, major roads, and flyovers. The source locations of $\mathrm{BC}_{\mathrm{bb}}$ were ubiquitous. Roadside burning of dry leaves is a common practice in Bengaluru, which might be the reason for the observed source pattern of $\mathrm{BC}_{\mathrm{bb}}$. In a similar analysis over Delhi, Dumka et al. (2019) observed distinct source locations for different pollutants. The CBPF analysis of $\mathrm{O}_{3}$ is presented in Fig. S7. From the figure, it was inferred that the sources of $\mathrm{O}_{3}$ are towards northwestern directions of the study site.

\section{CWT}

The trajectory cluster and CWT analysis for BC and $\mathrm{PM}_{2.5}$ are presented in Fig. 8. The CWT analysis of $\mathrm{BC}$ revealed that the potential long-range source regions (mostly the neighboring states) influencing the observed $\mathrm{BC}$ are towards the NNE (north-northeast; contributing $\sim \mu \mathrm{g} \mathrm{m}^{-3}$ and above) and NNW (north-northwest) directions (note the unavailability of $\mathrm{BC}$ data for the monsoon months). Similarly, $\mathrm{PM}_{2.5}$ CWT analysis revealed potential source contributions $\left(>30 \mu \mathrm{g} \mathrm{m}^{-3}\right.$ ) from regions (spanning up to Central India) in the NNE direction of the study site. The contributions from NNE regions were primarily during the post-monsoon season. Moderate contributions to $\mathrm{BC}$ and $\mathrm{PM}_{2.5}$ were observed from the Bay of Bengal region (mostly during the winter), while weak contributions to $\mathrm{PM}_{2.5}$ were observed from locations in the Arabian Sea (during monsoon). The CWT analysis of $\mathrm{O}_{3}$ is presented in the Fig. S8. From the figure, it was observed that the potential source contributions $(>33 \mathrm{ppb})$ from regions in the NNE direction of the study site.

\section{Health impact assessment}

The estimated attributable mortality cases due to LC and COPD were 147 (CI: 87-210) and 3413 (CI: 1888-5035), respectively, at a 95\% confidence interval (CI) (Table 4). The attributable mortality cases due to IHD and stroke (aged 25+) were 3393 (CI: 1766-5095) and 1016 (CI: 463-1605), respectively. The estimated number of attributable cases for IHD (629 (CI: 309-957)) and stroke (200 (CI: 88-318)) were observed to be the highest in the age group of 

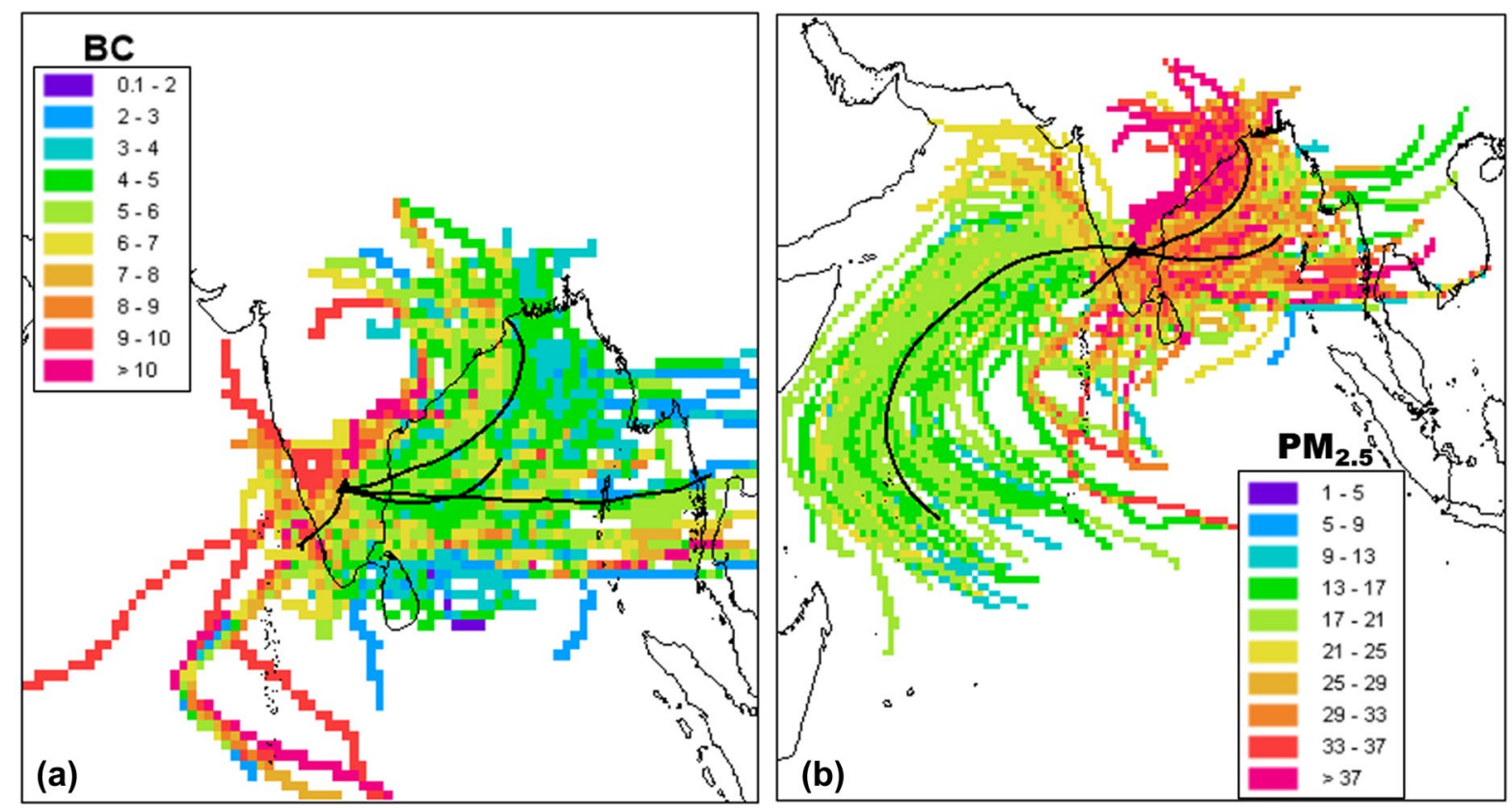

Fig. 8 Concentration-weighted trajectory (CWT) analysis of: (a) BC, and (b) $\mathrm{PM}_{2.5}$

50-54 years. The estimated number of attributable cases for mortality due to ALRI in children aged 0-5 years was 117 (CI: 83-151). Due to long-term exposure of $\mathrm{O}_{3}$, the estimated number of attributable cases for mortality due to respiratory diseases was 155 (CI: 56-263).

In an earlier study, Manojkumar and Srimuruganandam (2021) also reported that IHD is the leading contributor to $\mathrm{PM}_{2.5}$-induced mortality in Indian cities (viz., Chennai, Delhi, Faridabad, Gurgaon, Hyderabad, Kanpur, Lucknow, Nagpur, Thane, and Varanasi). The average IHD mortality in the analyzed cities was estimated to be 4079 (3706) in the male (female) population. Maheshwarkar and Sunder Raman (2021) also reported that the IHD is the major cause of premature mortality in the state of Madhya Pradesh, India, responsible for around $52 \%$ of total deaths, followed by Stroke ( $35 \%)$, COPD ( 11\%), and LC (1.2\%). Compared to the abovementioned studies, the attributable mortality observed in this study was less due to the observed lower $\mathrm{PM}_{2.5}$ in Bengaluru and the choice of baseline mortality data and RR values used for the mortality estimation.

\section{Limitations}

The current study suffers from the following limitations.

1. Part of the study period coincided with nationwide novel corona virus disease (COVID-19) lockdown, during which reduced anthropogenic activities-thereby, lowered pollution levelswere observed.

2. Black carbon data was not available during the monsoon due to instrument malfunction.

3. Successive moving average subtraction method was not applied on the $\mathrm{PM}_{2.5}$ data due to its coarse temporal resolution.

4. For PCA, pollutant data from CSTEP and the nearest CAAQMS data were combined.

5. For the health assessment, the ground-based point measurements from regulatory and CSTEP measured pollutant data were averaged to represent the city mean value. Also, the relative risk values were adopted (in AirQ+) from studies conducted outside India. 
Table 4 Mortality estimates due to long-term exposure of $\mathrm{PM}_{2.5}$

\begin{tabular}{|c|c|c|c|}
\hline Age & Mortality & $\mathbf{L C}$ & COPD \\
\hline $15-49$ & $2989(2014-3843)$ & $16(10-23)$ & $42(23-62)$ \\
\hline $50-69$ & $5075(3420-6525)$ & $77(46-110)$ & 2015 (1115-2973) \\
\hline $70+$ & $5710(3848-7341)$ & $54(32-77)$ & $1356(750-2000)$ \\
\hline Total & $13,774(9282-17,709)$ & $147(87-210)$ & $3413(1888-5035)$ \\
\hline Age & ALRI & & \\
\hline $0-5$ & $117(83-151)$ & & \\
\hline Age & IHD & Stroke & \\
\hline $25-29$ & $145(79-202)$ & $25(11-37)$ & \\
\hline $30-34$ & $131(71-188)$ & $23(11-35)$ & \\
\hline $35-39$ & $112(58-163)$ & $20(9-31)$ & \\
\hline $40-44$ & $92(47-135)$ & $16(7-25)$ & \\
\hline $45-49$ & $76(41-110)$ & $14(6-20)$ & \\
\hline $50-54$ & 629 (309-957) & $200(88-318)$ & \\
\hline $55-59$ & $497(268-736)$ & $154(73-238)$ & \\
\hline $60-64$ & $375(195-560)$ & $117(55-178)$ & \\
\hline $65-69$ & $262(137-399)$ & $82(34-128)$ & \\
\hline $70-74$ & $546(279-842)$ & $184(86-284)$ & \\
\hline 75-79 & 309 (167-467) & $102(50-165)$ & \\
\hline $80-84$ & $150(80-227)$ & $55(22-105)$ & \\
\hline $85-89$ & $53(26-82)$ & $18(8-30)$ & \\
\hline 90-94 & $13(7-21)$ & $5(2-9)$ & \\
\hline $95+$ & $3(1-4)$ & $1(0.4-1.5)$ & \\
\hline Total & 3393 (1766-5095) & $1016(463-1605)$ & \\
\hline
\end{tabular}

\section{Summary}

The current study showcases the temporal variation (at various scales) in $\mathrm{BC}, \mathrm{PM}_{2.5}$, and $\mathrm{O}_{3}$ and uses various statistical tools to identify the source locations and apportion their share to the observed receptor site pollution levels. Excess adult mortality due to longterm exposure to $\mathrm{PM}_{2.5}$ was also estimated for various health endpoints. The major results obtained from this study are summarized below:

- The study period mean ( \pm standard deviation) $\mathrm{PM}_{2.5}$, $\mathrm{BC}$, and $\mathrm{O}_{3}$ in northern Bengaluru was observed to be $26.8 \pm 11.5 \mu \mathrm{g} \mathrm{m}^{-3}, 5.6 \pm 2.8 \mu \mathrm{g} \mathrm{m}^{-3}$, and $25.5 \pm 12.4 \mathrm{ppb}$, respectively. Seasonal trends in $\mathrm{BC}$, $\mathrm{PM}_{2.5}$, and $\mathrm{O}_{3}$ revealed maximum concentrations during post-monsoon, winter, and summer, respectively.

- A $1 \mu \mathrm{g} \mathrm{m}^{-3}$ increase in hourly $\mathrm{BC}_{\mathrm{ff}}$ was found to be associated with a reduction of $1.8 \mathrm{ppb}$ of hourly $\mathrm{O}_{3}$. Contrastingly, a $1 \mu \mathrm{g} \mathrm{m}^{-3}$ increase in hourly
$\mathrm{PM}_{2.5}$ was found to be associated with an increase of 0.2 ppb of hourly $\mathrm{O}_{3}$.

- The local contribution of $\mathrm{BC}$ to the observed receptor site $\mathrm{BC}$ was found to be $\sim 23 \%$. The local contribution during the post-monsoon season was found to be statistically significant from that of the two seasons (winter and summer).

- Four principal components accounting for $76 \%$ of the cumulative variance in the pollutant and meteorological data were identified in the PCA.

- The CBPF analysis revealed that the source locations significantly contributing to the receptor site $\mathrm{BC}$ were towards the east of the study site, while they were located towards the northwest for $\mathrm{PM}_{2.5}$.

- The estimated attributable mortality due to longterm exposure of $\mathrm{PM}_{2.5}$ for the health endpoints COPD, IHD, stroke, and LC was around 3413, 3393,1016 , and 147, respectively.

- The estimated attributable cases due to long-term exposure of $\mathrm{O}_{3}$ for mortality from respiratory diseases were around 155 . 
Acknowledgements The authors acknowledge the funding support from MacArthur Foundation to Center for Study of Science, Technology and Policy (CSTEP) to conduct air pollution studies in Bengaluru. The authors acknowledge the Central Pollution Control Board (CPCB) and Karnataka State Pollution Control Board (KSPCB) for installing and maintaining the CAAQMS and making the data open access. The authors are grateful to Dr Jai Asundi and Mr Priyavrat Bhati for their support in establishing and maintaining the air pollution laboratory at CSTEP.

Data availability The regulatory (Pollution Control Board) datasets used during and/or analyzed during the current study are available on the CPCB dashboard (https://app.cpcbccr.com/ ccr/\#/caaqm-dashboard-all/caaqm-landing/data). The datasets generated from CSTEP during and/or analyzed during the current study are available from the corresponding author on reasonable request.

\section{Declarations}

Competing interests All the authors declare no competing interests.

\section{References}

Abbafati, C., Abbas, K. M., Abbasi-Kangevari, M., Abd-Allah, F., Abdelalim, A., Abdollahi, M., et al. (2020). Global burden of 87 risk factors in 204 countries and territories, 1990-2019: A systematic analysis for the Global Burden of Disease Study 2019. Lancet, 396, 1223-1249. https:// doi.org/10.1016/S0140-6736

Apte, J. S., Kirchstetter, T. W., Reich, A. H., Deshpande, S. J., Kaushik, G., Chel, A., et al. (2011). Concentrations of fine, ultrafine, and black carbon particles in autorickshaws in New Delhi, India. Atmospheric Environment, 45, 44704480. https://doi.org/10.1016/j.atmosenv.2011.05.028

Ashbaugh, L. L., Malm, W. C., \& Sadeh, W. Z. (1985). A residence time probability analysis of Sulfur at Grand Canyon national park. Atmospheric Environment, 19, 1263-1270. https://doi.org/10.1016/0004-6981

Babu, S. S., Satheesh, S.K., Moorthy, KK. (2002). Aerosol radiative forcing due to enhanced black carbon at an urban site in India. Geophysical Research Letters, 29, 1880. https://doi.org/10.1029/2002GL015826

Banerjee, T., Murari, V., Kumar, M., \& Raju, M. P. (2015). Source apportionment of airborne particulates through receptor modelling: Indian scenario. Atmospheric Research, 164-165, 167-187. https://doi.org/10.1016/j.atmosres.2015.04.017

Bond, T. C., Doherty, S. J., Fahey, D. W., Forster, P. M., Berntsen, T., Deangelo, B. J., et al. (2013). Bounding the role of black carbon in the climate system: A scientific assessment. Journal of Geophysical Research Atmospheres, 118, 5380-5552. https://doi.org/10.1002/jgrd.50171

Both, A. F., Balakrishnan, A., Joseph, B., \& Marshall, J. D. (2011). Spatiotemporal aspects of real-time $\mathrm{PM}_{2.5}$ : Low- and middle-income neighborhoods in Bangalore,
India. Environment Science and Technology, 45, 56295636. https://doi.org/10.1021/es104331w

Carslaw, D. C., \& Ropkins, K. (2012). Openair - An r package for air quality data analysis. Environmental Modelling \& Software, 27-28, 52-61. https://doi.org/10.1016/j.envsoft.2011.09.008

Cohen, A. J., Brauer, M., Burnett, R., Anderson, H. R., Frostad, J., Estep, K., et al. (2017). Estimates and 25-year trends of the global burden of disease attributable to ambient air pollution: An analysis of data from the Global Burden of Diseases Study 2015. Lancet, 389, 1907-1918. https://doi.org/ 10.1016/S0140-6736(17)30505-6

Drinovec, L., Močnik, G., Zotter, P., Prévôt, A. S. H., Ruckstuhl, C., Coz, E., et al. (2015). The "dual-spot" Aethalometer: An improved measurement of aerosol black carbon with real-time loading compensation. Atmospheric Measurement Techniques, 8, 1965-1979. https://doi.org/10.5194/ amt-8-1965-2015

Dumka, U. C., Tiwari, S., Kaskaoutis, D. G., Soni, V. K., Safai, P. D., \& Attri, S. D. (2019). Aerosol and pollutant characteristics in Delhi during a winter research campaign. Environment Science \& Pollution Research, 26, 3771-3794. https://doi.org/10. 1007/s11356-018-3885-y

Ganguly, T., Selvaraj, K. L., \& Guttikunda, S. K. (2020). National Clean Air Programme (NCAP) for Indian cities: Review and outlook of clean air action plans. Atmospheric Environment: $X, 8(2020)$, 100096. https://doi.org/10. 1016/j.aeaoa.2020.100096

Gurung, A., \& Bell, M. L. (2012). Exposure to airborne particulate matter in Kathmandu Valley. Nepal. Journal of Exposure Science \& Environmental Epidemiology, 22, 235-242. https://doi.org/10.1038/jes.2012.14

Gouda, K. C., Singh, P., Nikhilasuma, P., Benke, M., Kumari, R., Agnihotri, G., et al. (2021). Assessment of air pollution status during COVID-19 lockdown (March-May 2020) over Bangalore City in India. Environment Monitoring \& Assessment, 193, 1-13. https://doi.org/10.1007/ s10661-021-09177-w

Guttikunda, S. K., Nishadh, K. A., Gota, S., Singh, P., Chanda, A., Jawahar, P., et al. (2019). Air quality, emissions, and source contributions analysis for the Greater Bengaluru region of India. Atmospheric Pollution Research, 10, 941-953. https:// doi.org/10.1016/j.apr.2019.01.002

Henry, R. C., Lewis, C. W., Hopke, P. K., \& Williamson, H. J. (1984). Review of receptor model fundamentals. Atmospheric Environment - Part A, 84, 90375-90385. https:// doi.org/10.1016/0004-6981

HRAPIE. (2013). Health risks of air pollution in Europe: HRAPIE project recommendations for concentration response functions for cost-benefit analysis of particulate matter, ozone and nitrogen dioxide. World Health Organization.

Indian Council of Medical Research (ICMR)., Public Health Foundation of India (PHFI)., \& Institute for Health Metrics and Evaluation (IHME). (2019). GBD India compare data visualization. New Delhi: ICMR, PHFI, and IHME. https://vizhub.healthdata.org/gbd-compare/india. Accessed 10 Oct 2021.

Jia, M., Zhao, T., Cheng, X., Gong, S., Zhang, X., Tang, L., et al. (2017). Inverse relations of $\mathrm{PM}_{2.5}$ and $\mathrm{O}_{3}$ in air compound pollution between cold and hot seasons over an urban area 
of East China. Atmosphere, 8, 59. https://doi.org/10.3390/ atmos8030059

Kumar, M. K., Sreekanth, V., Salmon, M., Tonne, C., \& Marshall, J. D. (2018). Use of spatiotemporal characteristics of ambient $\mathrm{PM}_{2.5}$ in rural South India to infer local versus regional contributions. Environment Pollution, 239, 803-811. https:// doi.org/10.1016/j.envpol.2018.04.057

Kumari, S., Verma, N., Lakhani, A., Tiwari, S., \& Kandikonda, M. K. (2018). Tropospheric ozone enhancement during post-harvest crop-residue fires at two downwind sites of the Indo-Gangetic Plain. Environment Science \& Pollution Research, 25, 18879-18893. https://doi.org/10.1007/ s11356-018-2034-y

Lary, D. J., Lee, A. M., Toumi, R., Newchurch, M. J., Pirre, M., \& Renard, J. B. (1997). Carbon aerosols and atmospheric photochemistry. Journal of Geophysical Research: Atmospheres, 102(D3), 3671-3682. https://doi.org/10. 1029/96JD02969

Latha, K. M., \& Badarinath, K. V. S. (2004). Correlation between black carbon aerosols, carbon monoxide and tropospheric ozone over a tropical urban site. Atmospheric Research, 71, 265-274. https://doi.org/10.1016/j.atmosres.2004.06.004

Lawrence, M. G., \& Lelieveld, J. (2010). Atmospheric pollutant outflow from southern Asia: A review. Atmospheric Chemistry \& Physics, 10, 11017-11096. https://doi.org/10.5194/ acp-10-11017-2010

Mahapatra, P., Jena, J., Moharana, S., Srichandan, H., Das, T., Chaudhury, G., et al. (2012). Surface ozone variation at Bhubaneswar and intra-corelationship study with various parameters surface ozone variation at Bhubaneswar and intra-corelationship study with various parameters. Journal of Earth System Science, 121, 1163-1175. https://doi. org/10.1007/s12040-012-0216-4

Maheshwarkar, P., \& Sunder Raman, R. (2021). Population exposure across central India to PM2.5 derived using remotely sensed products in a three-stage statistical model. Scientific Report, 11, 1-13. https://doi.org/10.1038/s41598-020-79229-7

Mallik, C., Ghosh, D., Sarkar, U., Lal, S., \& Venkataramani, S. (2014). Variability of $\mathrm{SO}_{2}, \mathrm{CO}$, and light hydrocarbons over a megacity in Eastern India: Effects of emissions and transport. Environment Science \& Pollution Research, 21, 8692-8706. https://doi.org/10.1007/s11356-014-2795-x

Manojkumar, N., \& Srimuruganandam, B. (2021). Health effects of particulate matter in major Indian cities. International Journal of Environmental Health Research, 31, 258-270. https://doi.org/10.1080/09603123.2019.1651257

Mohammad, N. D., Ash'aari, Z. H., \& Othman, M. (2015). Preliminary assessment of air pollutant sources identification at selected monitoring stations in Klang valley, Malaysia. Procedia Environmental Sciences, 30, 121-126. https:// doi.org/10.1016/j.proenv.2015.10.021

Monge, M. E., D’Anna, B., Mazri, L., Giroir-Fendler, A., Ammann, M., Donaldson, D. J., et al. (2010). Light changes the atmospheric reactivity of soot. Proceedings of the National Academy of Sciences, 107, 6605-6609. https://doi.org/10.1073/pnas.0908341107

Nirmalkar, J., Deshmukh, D. K., Deb, M. K., Tsai, Y. I., \& Sopajaree, K. (2015). Mass loading and episodic variation of molecular markers in $\mathrm{PM}_{2.5}$ aerosols over a rural area in eastern central India. Atmospheric Environment, 117, 41-50. https://doi.org/10.1016/j.atmosenv.2015.07.003
Peshin, S. K., Sharma, A., Sharma, S. K., Naja, M., \& Mandal, T. K. (2017). Spatio-temporal variation of air pollutants and the impact of anthropogenic effects on the photochemical buildup of ozone across Delhi-NCR. Sustainable Cities Society, 35, 740-751. https://doi.org/10.1016/j.scs.2017.09.024

Prabhu, V., Soni, A., Madhwal, S., Gupta, A., Sundriyal, S., Shridhar, V., et al. (2020). Black carbon and biomass burning associated high pollution episodes observed at Doon valley in the foothills of the Himalayas. Atmospheric Research, 243, 105001. https://doi.org/10.1016/j.atmosres. 2020.105001

Rajashekara, S. (2020). Monthly and annual variation of temperature in urban habitats of the Bengaluru Region. India. Transactions on Science and Technology, 7(2), 29-34.

Revelle, W. (2016). psych: Procedures for personality and psychological research, Northwestern University, Evanston, Illinois, USA. http://CRAN.R-project.org/package=psych

Sarkar, S., \& Khillare, P. S. (2013). Profile of PAHs in the inhalable particulate fraction: Source apportionment and associated health risks in a tropical megacity. Environment Monitoring \& Assessment, 185, 1199-1213. https:// doi.org/10.1007/s10661-012-2626-9

Satheesh, S. K., Vinoj, V., \& Moorthy, K. K. (2011). Weekly periodicities of aerosol properties observed at an urban location in India. Atmospheric Research, 101, 307-313. https://doi.org/10.1016/j.atmosres.2011.03.003

Saxena, M., Sharma, S. K., Tomar, N., Ghayas, H., Sen, A., Garhwal, R. S., et al. (2016). Residential biomass burning emissions over Northwestern Himalayan region of India: Chemical characterization and budget estimation. Aerosol Air Quality Research, 16, 504-518. https://doi.org/10. 4209/aaqr.2015.04.0237

Seibert, P., Kromp-Kolb, H., Baltensperger, U., Jost, D. T., Schwikowski, M., Kasper, A., et al. (1994). Trajectory analysis of aerosol measurements at high alpine sites. In: B.P.M., B.P., C.T., S.W. (Eds.), Transport and Transformation of Pollutants in the Troposphere. Academic Publishing, Den Haag, 689-693.

Singh, R., \& Sharma, B. S. (2012). Composition, seasonal variation, and sources of $\mathrm{PM}_{10}$ from world heritage site Taj Mahal, Agra. Environment Monitoring \& Assessment, 184, 5945-5956. https://doi.org/10.1007/ s10661-011-2392-0

Soni, A., Decesari, S., Shridhar, V., Prabhu, V., Panwar, P., \& Marinoni, A. (2019). Investigation of potential source regions of atmospheric black carbon in the data deficit region of the western Himalayas and its foothills. Atmospheric Pollution Research, 10, 1832-1842. https://doi.org/ 10.1016/j.apr.2019.07.015

Sreekanth, V., Kushwaha, M., Kulkarni, P., Upadhya, A. R., Spandana, B., \& Prabhu, V. (2021). Impact of COVID-19 lockdown on the fine particulate matter concentration levels: Results from Bengaluru megacity, India. Advances in Space Research, 67, 2140-2150. https://doi.org/10.1016/j. asr.2021.01.017

Upadhya, A., Agrawal, P., Vakacherla, S., \& Kushwaha, M. (2021). pollucheck v1.0: A package to explore open-source air pollution data. Journal of Open Source Software, 6, 3435. https://doi.org/10.21105/joss.03435

Uria-tellaetxe, I., \& Carslaw, D. C. (2014). Conditional bivariate probability function for source identification. Environment 
Modelling \& Software, 59, 1-9.https://doi.org/10.1016/j. envsoft.2014.05.002

Vreeland, H., Schauer, J. J., Russell, A. G., Marshall, J. D., Fushimi, A., Jain, G., et al. (2016). Chemical characterization and toxicity of particulate matter emissions from roadside trash combustion in urban India. Atmospheric Environment, 147, 22-30. https://doi.org/10.1016/j.atmosenv.2016.09.041

Watson, J. G., \& Chow, J. C. (2001). Estimating middle, neighborhood and urban-scale contributions to elemental carbon in Mexico city with a rapid response aethalometer. Journal of Air \& Waste Management Association, 51, 1522-1528. https://doi. org/10.1080/10473289.2001.10464379
WHO. (2018). AirQ+ software tool for health risk assessment of air pollution [Accessed July 2021]. https:// www.euro.who.int/en/health-topics/environment-andhealth/air-quality/activities/airq-software-tool-forhealth-risk-assessment-of-air-pollution

Publisher's Note Springer Nature remains neutral with regard to jurisdictional claims in published maps and institutional affiliations. 